\title{
Anticancer Effect of a Typhonium flagelliforme L. in Raji Cells Through Telomerase Expression
}

\author{
Endang Purwaningsih ${ }^{*}$, Yulia Suciati ${ }^{2}$, Etty Widayanti ${ }^{1}$ \\ ${ }^{1}$ Department of Anatomy, Faculty of Medicine, YARSI University, Jakarta, Indonesia \\ ${ }^{2}$ Department of Biochemistry, Faculty of Medicine, YARSI University, Jakarta, Indonesia
}

\begin{abstract}
Cancer cells have a relatively high telomerase activity compared to normal cells, so the cancer cells have the ability to continue to proliferate and undergo mitosis uncontrolled. Telomerase is an enzyme which responsible for telomere length, a DNA segment that is at the end of eukaryotic cell chromosomes. Telomeres and telomerase play a role in the incidence of carcinogenesis. Natural materials such as taro mice (Typhonium flagelliforme) have potential as anticancer. The purpose of the study was to determine the effects of plant extracts of rat taro on the expression of telomerase in cancer cell Raji. The research method is experimental studies in some form cancerous cell culture cell line, Raji. Used as a control normal cells is Vero cell. The Culture medium used RPMI for Raji cell and MI99 for Vero cell. The study consisted of three groups, control, doses of I $1 / 2 I_{50}$ and IC 50 doses. Expression of telomerase enzyme was measured by the Immunohystochemistry method (IHC). The results showed that the expression of telomerase in cancer cells showed values significantly higher than the normal cells (Vero). Giving mice taro plant extracts (Typhonium flagelliforme) were able to decrease the expression of telomerase significantly in both treatment doses. It was concluded that rodent tuber extract (Typhonium flagelliforme Lodd) can reduce the expression of telomerase in Raji cells, so that the rodent tuber extract (Typhonium flagelliforme Lodd) has potential as an anticancer through the expression of telomerase.
\end{abstract}

Keywords: telomerase, IHC, Typhonium flagelliforme

\section{INTRODUCTION}

Nowadays, application of traditional medicine or natural material is increasing even though modern medicine has been advanced. Modern treatment costs are quite expensive and can cause side effects that are quite large, especially during cancer therapy, and the active compounds are less or not selective in killing cancer cells. Besides handling the tumor or cancer is still a lot of constraints, among others, are not sensitive to antiproliferative signals and able to avoid the apoptosis (Farida, et al., 2010, Son, et al., 2011). One of the therapeutic concern is chemotherapy used bioactive materials from a synthesis or isolation of natural materials, one of them is Keladi Tikus plant (Typhonium flagelliforme) (Chodidjah, et al., 2014; Purwaningsih, et al., 2014).

Telomere is a segment of DNA that exist at ends of chromosomes. It is one of the factors associated with the occurrence of cancer. Telomere length is also associated with age. Tall or short telomere is maintained by the telomerase enzyme that has specific RNA template and that is required to form a new telomere subunit. Telomerase activity in normal cells is mainly found in the reproductive cells because these cells have unlimited proliferative power. Whereas in cancer cells, telomerase activity is high enough (Artandi and DePinho, 2010).

Indonesia is known as one of the countries with the greatest biodiversity that has potential in the development of herbal medicine based on medicinal plants in development efforts in the field of health. The plants produce secondary metabolites compounds that have activity as anticancer such as alkaloids, terpenoids and flavonoids. One of the plants that contain potential compounds as an anticancer is Keladi Tikus plant (Typhonium flagelliforme Lodd) (Hariana, 2013).

The chemical content of Keladi Tikus plant has not been known. Phytochemical analysis results at the Research Institute of Medicinal and Aromatic Plants show that it contains alkaloids, saponins, steroids and glycosides, yet unknown active compound that specific to the Keladi Tikus plant that plays a role in curing cancer (Syahid and Kristina, 2007).

$\overline{* \text { Corresponding author e-mail: endpurwaning@gmail.com }}$ 
Extracts of sodium chloride Keladi Tikus leaves contain Ribosome Inactivating Protein (RIPs). Rips is a protein with an activity which able to cut the DNA or RNA of cancer cells thereby impacting in disable the growth of cancer cells without damaging surrounding tissue. In addition RIPs can also block the growth of cancer cells. (Syahid and Kristina, 2007; de Virgilio, 2010).

Considering the Keladi Tikus plant has potential as an anticancer and in general cancer cells showed high telomerase expression, then we want to know the potential Keladi Tikus plant extract on the expression of the telomerase enzyme in cancer cells. The research objective was to determine the expression of telomerase in cancer cell cultures Raji after being given Keladi Tikus plant extract (Typhonium flagelliforme Lodd).

\section{METHODS}

\section{Research Design}

This study was an experimental laboratory research with a case-control study design, consisted of two groups: Raji cells group and control group of normal cells (Vero). Each group consisted of three dose groups (control, dose $1 \frac{1 / 2}{2} \mathrm{IC}_{50}$ and $\mathrm{IC}_{50}$ ).

\section{Research Subject}

The experimental subjects were Raji cancer cell cultures (cell line) and normal cells (Vero) obtained from Parasitology Laboratory, Faculty of Medical, UGM. Cells were cultured in 24-wells microplate using RPMI medium (Rosewell Park Memorial Institute), each group performed in two replications. Cell cultures were incubated for 72 hours or until the cultures were confluent which had a density of $1 \times 10^{4}$ cells/wells. After the cultures were confluent, then the treatment performed in appropriately prescribed doses.

\section{Herbs/Plants Material}

Keladi tikus (Typhonium flagelliforme) was obtained from the medical plants garden in Jagakarsa, South Jakarta.

\section{Production of Medium for Cells Culture and Growth}

The cell culture medium was prepared by dissolving one sachet of powder RPMI and M199 into $800 \mathrm{~mL}$ of aquabidest approximately, then 2.0 grams sodium bicarbonate and 2.0 grams HEPES was added, at the last aquabidest was added up to one liter of solution. The solution was stirred for about 10 minutes with a magnetic stirrer until it was homogeneous. After that, the homogenuos solution was neutralized by adding $1 \mathrm{~N} \mathrm{HCl}$ to obtain $\mathrm{pH}$ at 7.2 to 7.4 .

The growth cells medium prepared by mixing FBS as much as $19 \mathrm{~mL}, 2 \mathrm{~mL}$ penicillinstreptomycin, and $0.5 \mathrm{~mL}$ Fungizone, then diluted in culture medium up to $100 \mathrm{~mL}$. Furthermore, the solution is filtered with $0.2 \mu \mathrm{m}$ sterile polyethylene sulfone filter aseptically. The medium was stored in the refrigerator by using a sealed bottle.

\section{Preparation of Keladi Tikus Extract}

Keladi tikus extract (from the whole plant) was made by this way: all the fresh plants was washed and sliced thinly then it was dried. After that, the chopped was powdered. The powder was macerated with $80 \%$ ethanol in erlenmeyer while doing a continous shuffling. The ethanol extract then was transferred into rotary flask and concentrated using rotary evaporator. Concentrated extract of keladi tikus was dissolved in DMSO, then it diluted to obtain a series of concentrations and filtered with $0.2 \mu \mathrm{m}$ filter before it was put into 24-wells plate.

\section{Examination of the Telomerase Expression through Immunohystochemistry Method/IHC}

HeLa cells culture, T47D and Vero with density $10^{4}$ cells/well plate that have been stuck on coverslip conducted immunochemistry staining (IHC) in Parasitology laboratory Faculty of Medicine, UGM. The procedure of telomerase expression observation through IHC as the following :

Cells culture on the coverslip that has been given treatment and incubated in incubator $5 \% \mathrm{CO}_{2}$ at $37^{\circ} \mathrm{C}$ for 24 hours was taken and put on the object glass ((poly-l-lysine slide), fixate by aceton or methanol for 10 minutes at $-20^{\circ} \mathrm{C}$, then washed with PBS 3 times, 5 minutes and given some drops of norma lmouse serum (1:50) for 15 minutes and dispose the liquid (without washed). Then the object glass was given same drops of primer antibody (telomerase) for 60 minutes. Washed in PBS 3 times, each for 5 minutes, then incubate in the biotin secondary antibody (biotinylated secondary 
antibody) for 5-10 minutes, washed with PBS 3 times, each for 5 minutes. Incubate in streptavidinproxyde enzyme for 5-10 minutes, washed with PBS 3 times, each for 5 minutes. Incubate in Kromogen deaminobenzidin tetrahidroklorid (DAB) for 10-15 minutes with comparison substrate chromogen 1 : 20, then washed with aquadest. Preparation was soaked in hematoksilin for 3-5 minutes for counterstain, wash with aquadest and dehydrate using ethanol 95\%, then with xylen each for 10 minutes. Then, preparation was given some drops of mounting media (Canada balsem) and covered using cover glass. Telomerase expression was observed using light microscope. Cell that expressing telomerase will give brown color, while cell that doesn't express telomerase will give purplish blue color.

\section{Data Analysis}

Data analyzed use statistical Anova test followed by multiple comparison test with SPSS 18 version.

\section{RESULT AND DISCUSION}

Before IHC assay performed to telomerase expression, cytotoxicity assay was performed and gotten $\mathrm{IC}_{50}$ score $53.799 \mu \mathrm{g} / \mathrm{mL}$. Telomerase expression observation by IHC method was performed by calculate the amount of cell that shows positive expression (brown color) from 100 cells were examined. The result was represented in percent. This study uses cancer cells in cell line and normal cells as control that is Vero normal cell and lymphoma cancer cells, Raji cells. Percentage score of positive telomerase expression of the three groups with eatch treatment dosage showed in Tabel 1. Telomerase expression on Raji cancer cells showed higher expression than on normal cells (Vero). From statistical analysis using ANOVA, there was lower expression of telomerase on Raji cell group than control group (Vero) after being treated with keladi tikus extract. Statistical analysis using LSD of telomerase expression of each group was performed in Table 2.

Table I. Expression of telomerase on control group and case group

\begin{tabular}{ccccccc}
\hline \multirow{2}{*}{ Replication } & \multicolumn{3}{c}{ Vero (control) } & \multicolumn{3}{c}{ Raji } \\
\cline { 2 - 7 } & K & I/2IC & IC & K & I/2IC & IC \\
\hline I & 5 & 0 & 0 & 67 & 23 & 9 \\
2 & 3 & 1 & 0 & 67 & 23 & 12 \\
3 & 3 & 1 & 0 & 67 & 22 & 12 \\
Mean & 3.667 & 0.667 & 0 & 67 & 22.667 & 11 \\
SD & 1.155 & 0.577 & 0.000 & 0.000 & 0.577 & 1.732 \\
\hline
\end{tabular}

Table 2. Least Significant Different of positive telomerase expression of each group

\begin{tabular}{|c|c|c|c|c|c|c|}
\hline Group & Vero K & $\begin{array}{c}\text { Vero } 1 / 2 \\
I C_{50}\end{array}$ & $\begin{array}{c}\text { Vero I } \\
I^{\prime C_{50}}\end{array}$ & $\begin{array}{c}\text { Raji } \\
\mathbf{K}\end{array}$ & $\begin{array}{c}\text { Raji } \\
1 / 2 \mid \mathbf{C}_{50}\end{array}$ & $\begin{array}{c}\text { Raji } \\
\text { I IC }\end{array}$ \\
\hline Vero K & - & - & - & $* *$ & $* *$ & $* *$ \\
\hline Vero $1 / 2 I_{50}$ & - & - & - & $* *$ & $* *$ & $* *$ \\
\hline Verol IC50 & - & - & - & $* *$ & $* *$ & $* *$ \\
\hline Raji Kontrol & $* *$ & $* *$ & ** & - & - & - \\
\hline Raji $1 / 2$ IC 50 & ** & $* *$ & ** & - & - & - \\
\hline Raji I IC 50 & $* *$ & $* *$ & ** & $* *$ & - & - \\
\hline
\end{tabular}


Telomerase is ribonucleoprotein which has a function to maintain the protection structure on the end of chromosome called telomere. Telomerase has responsibility telomere maintenance, a replicated nucleotide (TTAGGG) n. In somatic cells like fibroblast, telomerase expression is reduced and telomere would progressively shorter in every cell division. Otherwise, tumor cells or cancer cells in human steadily express telomerase. Maintenance of telomerase become very important on tumor or cancer cells. Telomerase activity determines the cell proliferation of tumor or cancer cells in vivo or in vitro condition (Quelette, et al., 2011). In normal cells like fibroblast, telomerase activity like hTERT (human telomerase reverse transcriptase) and telomere length determine the aging process. Interference of telomerase activity on normal cells would slow down cell proliferation, limit cell age, and change maintenance of three single stands telomeric overhang without affecting telomere shortening. There is a difference of telomere activity between normal stem cells and cancer stem cells (Masutomi, et al., 2003; Shay and Wright, 2011).

Raji cell using in this study is cell line culture of lymphoblastoid derived from lymphoma Burkitt (BL), which has high expression of BAFF ( $B$ cell activating factor belonging to TNF family). Inhibition of BAFF and its receptor would inhibit telomerase expression on Raji cells (Zhang, et al., 2011).

In this study, telomerase expression (appearance by TERF-2 concentration) in lymphoma cancer cells (Raji cells) was significantly higher than the concentration TERF-2 on normal Vero cells (fibroblasts). Researchers have previously reported, that cancer cells generally have high telomerase activity compared to normal cells (Artandi \& DePinho, 2010), such as a non-Hodgkin lymphoma cell (Ely, et al., 2000). Telomerase activity in lymphoma cell is varied and show characteristics in different types of B-cell non-Hodgkin lymphoma (BNHL).

Other studies have linked the expression of telomerase in cancer cells has been done by previous researchers in HeLa cells using triethylene tetraamin (TETA) using modified telomeric repeat amplification (TRAP) and flowsitometri method. It was reported that triethylene tetraamin (TETA) in micromolar concentrations can inhibit the proliferation of HeLa cells at the G1 phase.
Telomerase activity in HeLa cells and T47D cells is quite high and the cells rapidly divide or high proliferation rate. This raises a thought their telomerase inhibitor that acts as a cancer therapy, through the molecular mechanism (Ivankovic, et al., 2007, Nasiri, et al., 2013).

Research in vivo were performed in patients with colon cancer, also reported the expression of telomerase subunit hTERT (human telomerase reverse transcriptase), HTR (human telomerase RNA), and TP1 (TEP1) (telomerase-associated protein 1) in colon cancer cells was higher than the expression of telomerase in normal cells. Therefore, telomerase could be a marker that is good enough for the incidence of cancer (Nowak, et al., 2003).

In addition telomerase activity in pancreatic cancer cells also showed a high expression compared with normal cells. Telomerase activity examined in both specimens pancreatic cancer and metastatic lesions. The result showed telomerase activity in cancer cells with metastatic lesions was higher than primary tumor cells. Lower telomerase activity was found in non-malignant pancreatic cell disorders such as benign, acute and chronic adenomas (Zizuh and Hans, 2012).

Provision of keladi tikus extract can lower the expression of telomerase in cancer cells, Rajibaik at doses $1 / 2 \quad \mathrm{IC}_{50}$ and $1 \mathrm{IC}_{50}$ dose. This suggests that agents/compounds in keladi tikus extracts have a potential as an agent/anticancer compounds on Raji cells or lymphoma cell. The previous research is reported that there are four active fraction contained in keladi tikus that is pheophorbide-a, pheophorbidea', and pyropheophorbid pyropheophorbide-a-a'. Other compounds which have also been identified is oleic acid, linoleic acid, stigmasterol and beta sitosterol. (Lai, et al., 2010). In this case alleged, that the factions can lowering the expression of telomerase in Raji cells.

The short telomeres in cancer stem cells may reflect the multistep nature of cancer initiation against drugs or antineoplastic. In some culture of tumor cells, telomerase activity is decreased after treatment with antineoplastic drugs (Sakin, et al., 2008). Typhonium flagelliforme extract also decreased the expression of telomerase in Raji cells. A previous study report that Typhonium flagelliforme extract decrease the expression of telomerase in cells MCF -7 and Widr at different doses (Purwaningsih, et al., 2014b). 
The subline MCF is reported resistant to doxorubicin and vincristine. The resistances of these drugs are not directly related to the level of expression of hTERT and telomerase activity levels (Sakin, et al., 2008). Other studies have reported that T47D cells also have high telomerase activity. Provision of curcumin and silibinin can inhibit the growth or proliferation of T47D cells and decrease the expression of genes hTERT (human telomerase Reverse Transcriptase) (Nasiri, et al., 2013).

\section{CONCLUSION}

The Typhonium flagelliforme extract can reduce the expression of telomerase in Raji cells. It indicates a potent chemoprevention of the extract against the expression of telomerase.

\section{SUGGESTION}

Further research is needed to determine the effect of Typhonium flagelliforme extract to the length of telomere nucleotides that plays a role in the incidence of cancer.

\section{ACKNOWLEDGEMENT}

The author would like to thank to the Directorate General of Higher Education on financial assistance for the implementation of this study.

\section{REFERENCES}

Artandi, S.E. and DePinho, R.A., 2010, Telomeres and Telomerase in Cancer, Carcinogenesis, 3I(I), 9-I8.

Chadidjah, Nasihun, T., Widayati, E. and Goenarwo, E., 2014, Typhonium Flagelliforme Decreases Protein Expression in Murine Breast Cancer, Univ. Med., 33(3), 161-170.

Ely, S.A., Cadburn, A., Dayton, C.M., Cesarman, E. and Knowwies, D.M., 2000, Telomerase Activity in B-Cell Non Hodgkin Lymphoma, Cancer, 89(2), 446-452.

Farida, Y., Rahayu, L. and Faizatun, 2010, Aktivitas Antioksidan Serbuk n-Heksana dan Metanol Hasil Pengeringan Semprot Ekstrak Keladi Tikus (Typhoniu flagelliforme L.) Decue, Proceding, Makassar: Kongres IImiah XVIII Ikatan Apoteker Indonesia 2010, 10-12 Desember 2010
Hariana, H.A., 20I3, Tumbuhan Obat dan Khasiatnya, Jakarta: Penerbit Swadaya.

Ivankovic, M., Cukusic, A. and Gotic I., 2007, Telomerase Activity in HeLa Cervical Carcinoma Cell Line Proliferation, Biogerontology, 8(2), I63-I 72.

Lai, C.S., Mas, R.H., Nair, N.K., Mansor, S.M. and Nayaratnam, V., 2010, Chemical Constituent and in vitro Anticancer Activity of Typhonium Flagelliforme (Aracaceae), J. Ethnopharmacol., I 27(2), 486-94.

Masutomi, K., Yu, F.Y., Khurts, S., Ben-Porath, I., Currier, J.L., Metz, G.B., et al., 2003, Telomerase Maintans Telomere Structure in Normal Human Cells, Cell, I I4(2), 24I253.

Nasiri. M., Zhargami, N., Koshki, K.N., Mollazadeh, M., Moghaddam, M.P., Yamchi, M.R., et al., 2013, Curcumin Silibinin Inhibit Telomerase Expression in T47D Human Breast Cancer Cells, Asian Pasific J. Cancer Prev., I4(6), 3449-3453.

Nowak, J., Januszzkiewicz, Lewandowski, K., Nowicka-Kujawska, K., Pernak, M., Rembowska, J., et al., 2003, Activity and Expression of Human Telomerase in Normal and Malignant Cells in Gastric and Colon Cancer Patient, Eur. J. Gastroenterol., I 5(I), 75-80.

Purwaningsih, E., Widayanti, E. and Suciati, Y., 2014a, Cytotoxicity Assay of Typhonium flagelliforme Lodd Against Breast and Cervical Cancer Cells, Univ. Med., 33(2), 75-82.

Purwaningsih, E., Suciati, Y. and Widayantie, 20l4b, Effect of Rodent Tuber Extract (Typhonium flagelliforme L.) against Telomerase Expression in MCF7 and Widr Cell Culture, Proceding, Solo: Simposium Penelitian Bahan OBAT Alami (SPBOA) XVI dan Muktamar XII PERHIPBA 20I4, ISBN: 978-602-225-86I-2, PP. 95-101.

Quellette, M.W., Wright, W.E. and Shay, J.W., 20I I, Targeting Telomerase-expressing Cancer Cells, J. Cell. Mol. Med., I 5(7), I433-I 442.

Sakin, V., Eskiocak, U., Kars, M.D., Iseri, O.D. and Gunduz, U., 2008, hTERT Gene Expression Levels and Telomerase Activity in Drug Resistant MCF-7 Cells, Exp. Oncol., 30(3), 202-205.

Shay, J.W. and Wright, W.E., 2010, Telomeres and Telomerase in Normal and Cancer Stem Cells, FEBS Letters, 2584(I7), 3819-3825.

Syahid and Kristina, N.N., 2007, Induksi dan Regenerasi Kalus Keladi Tikus (Typhonium flagelliforme Lood) Secara in vitro, Jurnal Littre, I3(4), |42-| 46. 
de Virgilio, M., Lombardi, A., Caliandro, R. and Fabbrini S., 2010, Ribosom in Activating Protein: from Plant Defense to Tumor Attack, Toxin, 2(II), 2699-2737.

Zhang, L., Jiang, Y., Zheng, Y., Zeng Y., Yang Z., Haung, G., et al., 20II, Selective Killing of Burkitt's Lymphoma Cells by mBAFF- targeted Delivery of PinXI, Leukimia, 25(2), $33 \mathrm{I}-340$.

Zisuh, A.V. and Han, T.Q., 2012, Expression of Telomerase and Its Significance in the Diagnosis of Pancreatic Cancer, Indian J. Med. Res., I35(I), 26-30. 